\title{
Rare Book Code
}

\section{UNIVERSITY OF CALIFORNIA}

The University Library

Los Angeles 24, California

Office of the Librarian

\section{MEMORANDUM TO THE STAFF ON RARE BOOKS}

The Library has a twofold purpose; to serve people, to conserve books. We are judged by the present on how well we serve from day to day. The future will judge us by how wisely we have conserved the research treasure which we inherited, increased, and willed to our successors.

An evidence of a Library's cultural maturity is the care given to its scarce and irreplaceable materials. Its workers must be able to recognize such books at any point on the belt line of acquiring, cataloging and shelving.

I am asking that every member of the staff share this responsibility of seeing that valuable books be given special handling. Normally the Acquisitions department screens them out of purchases, gifts, and exchanges for review, but the volume handled there is increasingly heavy, and fugitive items will sometimes escape through the finest mesh. Then it is up to the catalogers, and finally the loan and shelf people, to sequester these items which cannot be entrusted to the perils of the stack.

No rules-of-thumb can be devised which will take the place of personal knowledge, intelligence, and discrimination. Attached however is a list of preliminary criteria for recognizing possible rarities which is used by the Acquisitions department. All staff members are asked to study and be guided by it.

\section{Lawrence Clark Powell}

\section{RARE BOOKS}

Books and periodicals in the following categories may be considered for inclusion in the Rare Book collection and will be held in Acquisitions for review before accessioning. Inclusion in one of the classes is not tantamount to rarity, and the list is not necessarily definitive. The possibility of rarities outside these criteria must always be recognized. Books finally accepted as Rare will be so designated and given special handling (i.e. the legend will be pencilled lightly along the inner margin of the page following the title page; all ink stamping, perforating, etc., will be omitted; the call number, preceded by a triangle, will be pencilled inside the front cover and inked on a small label pasted to the lower right corner of the back cover; special care will be taken in plating, so that, for example, original bookplates are not removed or pasted over). Current Rare periodical issues will not be date-stamped, will be carefully marked with a pencilled triangle, and shelved with the Rare Books. All Rare materials will be given special care in binding, after consultation with the Head of Special Collections. Hand-binding or the use of boxes will be considered; covers, advertisements, etc., must be preserved intact. 
This code applies also to Branch Libraries, for it is recognized that specialized Rare Book Collections exist and will develop in Branch Libraries, as in the history of chemistry and medicine. Branch Libraries will consult the Head of Special Collections on matters of housing, care, etc.

1. Books of value due to early imprint date.

a. All books printed before 1600 .

b. American books printed before 1820 .

In states west of the Appalachians, according to date printing started (California books printed before 1870; Los Angeles books printed before 1900).

2. Books whose irreplaceability or uniqueness makes them rare.

a. Limited editions (300 copies or less).

b. Association and autographed copies, when by important or local authors.

c. First editions of significance.

3. Books of esthetic importance (fine printing, illustration, or binding).

4. Books which cost the library more than $\$ 50$, or which have a similar auction record.

5. Items of local or archival value or interest, including local fine press books.

6. Erotica, excluding sex hygiene, scientific works on sex, etc.

7. Other books subject to loss or damage.

a. Volumes or portfolios of fine or loose plates.

b. Books whose illustrations make them subject to mutilation.

c. Books of fragile physical make-up.

8. Special collections, i.e. unit acquisitions containing both rare and non-rare material, which need to be kept together.

9. Books with significant manuscript or other materials laid or tipped in. 